\title{
Response surface for sugars extracted from lignocellulosic material providing low energy expenditure
}

\section{Obtenção da superfície de resposta para açúcares extraídos de material lignocelulósico propiciando baixo gasto energético}

\author{
Fabiana da Silva Pieta ${ }^{1}$; Reinaldo Aparecido Bariccatti ${ }^{2}$
}

\begin{abstract}
The objective of this work was the extraction of sugars from the sugarcane bagasse from the chemical pretreatment with diluted sulfuric acid, with a factorial planning of 3 factors with two levels each. The levels of 5 and $15 \mathrm{~g}$ for sample mass, two variations of 5 and $10 \%$ acid concentration and 25 and $50^{\circ} \mathrm{C}$ temperature variations were adopted. The characterization of the hydrolyzate was done through the refractive index and by high performance liquid chromatography. For the refractive index, the tests 3, 7 and 8 had the highest amount of soluble solids extracted, being $13.005 ; 13.025$ and $13.010^{\circ}$ Brix, respectively. According to the effects obtained from the results of the refractive index, the only significant main effect is the increase in acid concentration, which increases the refractive index. In the results obtained by liquid chromatography, we were able to identify the presence of glucose, xylose and cellobiose in the solutions and the condition that resulted in a higher extraction of sugars was: $15 \mathrm{~g}$ biomass, $10 \%$ acid concentration and temperature at $50{ }^{\circ} \mathrm{C}$. With the concentration of the acid in the upper limit (10\%) the sugar extraction in this work was significant with $13.025 \mathrm{gL}^{-1}$.
\end{abstract}

Keywords: Sugarcane bagasse. Factorial planning. Chemical pre-treatment.

\section{Resumo}

Objetivou-se com esse trabalho a extração de açúcares do bagaço de cana-de-açúcar a partir do pré-tratamento químico com ácido sulfúrico diluído, com um planejamento fatorial de 3 fatores com dois níveis cada. Foram adotados os níveis de 5 e $15 \mathrm{~g}$ para massa da amostra, duas variações de concentração do ácido 5 e $10 \%$ e a variação de temperatura 25 e $50{ }^{\circ} \mathrm{C}$. A caracterização do hidrolisado se deu através do índice de refração e por cromatografia líquida de alta eficiência. Para o índice de refração, os ensaios 3, 7 e 8 tiveram maior quantidade de sólidos solúveis extraído, sendo 13,$005 ; 13,025$ e 13,010 ${ }^{\circ}$ Brix, respectivamente. Segundo os efeitos obtidos a partir dos resultados do índice de refração, o único efeito principal significativo é o aumento da concentração de ácido, que aumenta o índice de refração. Nos resultados obtidos por cromatografia líquida, conseguimos identificar a presença de glicose, xilose e celobiose nas soluções e a condição que resultou numa maior extração de açúcares foi: $15 \mathrm{~g}$ de biomassa, $10 \%$ de concentração de ácido e temperatura a $50{ }^{\circ} \mathrm{C}$. Com a concentração do ácido no limite superior (10\%) a extração de açúcares nesse trabalho foi significativa com $13,025 \mathrm{gL}^{-1}$.

Palavras-chave: Bagaço de cana-de-açúcar. Planejamento fatorial. Pré-tratamento químico.

\footnotetext{
${ }^{1}$ Mestranda em Eng. de Energia na Agricultura, UNIOESTE, Cascavel, PR, Brasil; E-mail: fabipietasl@gmail.com

${ }^{2}$ Prof. Dr., Centro de Engenharia e Ciências Exatas, UNIOESTE, Toledo, PR, Brasil; E-mail: reinaldo.bariccatti@ unioeste.br
} 


\section{Introduction}

Among the lignocellulosic materials, sugarcane bagasse is one of the most prominent in Brazil, currently it is used in boilers for co-generation of steam and electric power (FERNANDES et al., 2017), but the use of this residue for the production of liquid biofuels is an extremely favorable way for the final destination of biomass, among them, second generation ethanol that has a promising potential (RAELE et al., 2014).

One of the advantages of sugarcane bagasse is that it is available in large quantities and with minimal cost in relation to transport (FERNANDES; MIGUEL, 2011). According to data from Companhia Nacional de Abastecimento - National Supply Company (CONAB, 2017), total sugarcane ground in the 2017/2018 harvest was 646.4 million tons, producing 26.12 billion liters of ethanol. dry sugarcane bagasse, the yield varies between 158 and 335 L/ton (CARPIO; SOUZA, 2017).

According to MILANEZ et al. (2015), the secondgeneration ethanol in Brazil has the potential to increase productivity by up to $50 \%$ compared to the current production, due to the efficiency and quantity of these lignocellulosic materials. Regarding their structure, lignocellulosic materials are composed of $32-50 \%$ cellulose, $19-25 \%$ hemicellulose, $23-32 \%$ lignin, extractives and ash, however depending on the species the proportion of these components may vary (BRIENZO et al., 2004 SUN et al., 2016).

The difficulty of converting the lignocellulosic materials into sugars is attributed to the chemical and morphological characteristics and the pretreatment is carried out with the purpose of increasing the surface area of the biomass, increasing its porosity and reducing the crystallinity of the cellulose (SANTOS-ROCHA et al., 2017). Pretreatment with diluted sulfuric acid is responsible for promoting the dissolution of hemicellulose and the formation of a solid fraction rich in cellulose and lignin (ASSUMPTION et al., 2016).

However, effective pretreatment is characterized by minimizing energy expenditure, avoiding physical treatment of biomass and having a low cost reagent, thus reduc-ing these steps for the treatment of biomass is necessary to have a lower cost, lower environmental impact and higher yields in obtaining biofuels (SILVEIRA et al., 2015).

The objective of this work is the extraction of sugars from sugarcane bagasse from the chemical pretreatment with diluted sulfuric acid, with factorial planning of 3 factors with two levels each. The levels of 5 and $15 \mathrm{~g}$ for sample mass, two variations of 5 and $10 \%$ acid concentration and 25 and $50{ }^{\circ} \mathrm{C}$ temperature variations were adopted. Quantification of the hydrolyzate was done through the refractive index and by high performance liquid chromatography.

\section{Materials and methods}

\section{Specifications and preparation of biomass}

For the study, sugarcane bagasse was used, which was sold by establishments selling sugarcane juice in the city of Cascavel, PR, Brazil (24 57' 21" S, 53 27' 19" W and $781 \mathrm{~m}$ altitude). The analyzes were carried out at the Biodiesel Laboratory at the State University of the West of Paraná (UNIOESTE), Cascavel campus.

For the washing stage, the biomass was allowed to stand for 2 hours in distilled water, after which it was dried in an oven with forced air circulation for 12 hours at $65^{\circ} \mathrm{C}$.

The last step was the adequacy and standardization of bagasse size for pre-treatment. In the present work the particle size was determined approximately $5 \mathrm{~cm}$ and later ground in a domestic processor for better reduction of particle size and surface area increase.

\section{Acid pretreatment}

For the acid pretreatment the diluted sulfuric acid was used, the concentrated acid solution was diluted in acid/water ratios 1:10; 1:15 and 1:20 (v/v) and used without standardization.

The acid pretreatment procedure was carried out with variations in temperature, acid concentration and amount of raw material in order to determine which operating condition was most favorable to the solubilization of hemicellulose. Pretreatment conditions were determined by a literature review.

Thus, for factorial planning, the levels of 5 and 15 $\mathrm{g}$ for sample mass, two variations of 5 and $10 \%$ acid concentration and 25 and $50{ }^{\circ} \mathrm{C}$ temperature variations were adopted. The procedure was done in duplicate and the solutions at the central point $\left(10 \mathrm{~g}, 7.5 \%, 37.5^{\circ} \mathrm{C}\right)$ in triplicate were used to estimate the error.

\section{Quantification and characterization of sugars}

The total soluble solids content (TSS) allows to verify the dilution or concentration of broths after processing. Expressed in ${ }^{\circ}$ Brix is the percentage, by weight, of total 
solids (sugars, polysaccharides, proteins, minerals) dissolved in the broth. The analyzes were performed in a bench refractometer in duplicate. The equipment was calibrated with distilled water.

The characterization of the solutions was performed on Shimadzu's LC-20A Prominence equipment with Phenomenex Rezex ROA-Organic Acid H + column (8\%) $(300 \times 7.8 \mathrm{~mm})$ at $65^{\circ} \mathrm{C}$. The mobile phase consisted of a $0.005 \mathrm{~N}$ sulfuric acid solution (H2SO4), flowing $0.6 \mathrm{~mL}$ $\min ^{-1}$. The solution was diluted 1:10 (v/v) using ultra pure water. The $\mathrm{pH}$ adjustment was done according to the method of Sluiter et al (2008) with calcium carbonate (0.23 g).

After filtration in Sep Pak C18 filter cartridges (for removal of interferents) and then on $0.45 \mu \mathrm{m}$ membrane filter (for particle removal). The injected volume of the solution was $20 \mu \mathrm{L}$. Carbohydrates (cellobiose, glucose, xylose, arabinose) were quantified by the refractive index detector (RID - 10A). For the quantitative analysis, standard curves were made, using the range of 0.05 ; 0.075 ; $0.15 ; 0.25 ; 0.35 ; 0.5 ; 1.0$ and $1.5\left(\mathrm{gL}^{-1}\right)$ for cellobiose, glucose, xylose and arabinose. The analyzes were done in duplicates.

The results were submitted to statistical analysis and surface treatment of the effects of each variable, amount of biomass, acid concentration and temperature on the sugar concentration. Chemoface software (version 1.61) was used, which enabled the response surfaces to be obtained according to the studied variables, as well as the significant effects, the $\mathrm{p}$-value for regression and the lack of adjustment.

\section{Results and discussion}

In the present work, the mass and temperature variables showed little influence on the extraction of the soluble solids in relation to the acid concentration, which at $10 \%$ gave us a better result. In Table 1 we can see that solutions 3,7 and 8 stood out with $13.005 ; 13.025$ and $13.01{ }^{\circ}$ Brix, respectively. In solution 5 we obtained the lowest extraction, with $6.56^{\circ}$ Brix.

In the study of Oladi and Aita (2017), in two varieties of sugarcane bagasse, from a pre-treatment with ammonium hydroxide, with temperature between $116-220{ }^{\circ} \mathrm{C}$ for a time of $30-60 \mathrm{~min}$, the obtained brix was $(2 \% \mathrm{NaOH}$, $85^{\circ} \mathrm{C}, 1 \mathrm{~h}$ and $10 \% \mathrm{H}_{2} \mathrm{SO}_{4}, 100^{\circ} \mathrm{C}, 30 \mathrm{~min}$ ) was obtained by the use of a combined pre-treatment (cut, grind, boil) 80 and $50{ }^{\circ}$ Brix, respectively.
There are a large variety of lignocellulosic biomasses, so each one has its unique chemical combination, which makes it difficult to find the proper method and conditions (RAUD et al., 2015). However, if the conditions provide high yield, minimum energy expenditure, being sustainable and economically feasible, they are considered efficient (SILVEIRA et al., 2015).

According to the effects obtained by the treatment of the results, the only significant main effect is the increase of the acid concentration, which increases the refractive index (Brix) by 0.0051. However, the mass / acid, acid / temperature and acid / mass / temperature interactions are significant.

However, the increase of acid and mass decreases the value of refraction index by -0.0046 , since for acid increase and temperature it increases the refractive index of 0.0046 and lastly the effect between the interactions of the 3 variables studied causes a increase of 0.0039 in the mean value of the refractive index. In this sense, it is important to emphasize that the operational conditions of pre-treatments described in the literature, such as acid concentration, temperature and mass vary widely.

\section{Response surface}

When analyzing the response surface for the extraction of soluble solids, it can be seen that acid concentration and mass in Figure 1 were the two main factors that interfered in the extraction of the hemicellulosic hydrolyzate.

Figure 1 - Response surface for the amount of soluble solids extracted as a function of the variables mass $(\mathrm{g})$ and acid concentration $(\%)$ at a temperature of $37.5^{\circ} \mathrm{C}$.

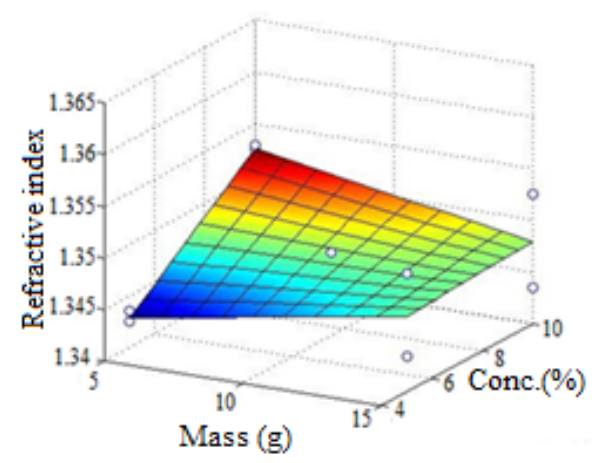

Source: The authors.

For these two independent variables, the higher level $(+1)$ of acid concentration and the lower level (-1) of the mass quantity resulted in a hydrolyzate with a higher amount of soluble solids, that is, the lower the mass and higher acid concentration, more soluble solids were extracted. 
Table 1 - Mean and standard deviation of the soluble solids obtained by refractometer in ${ }^{\circ}$ Brix.

\begin{tabular}{ccccc}
\hline Factors & Upper limit (-) & \multicolumn{3}{c}{ Bottom limit $(+)$} \\
\hline A - Mass $(\mathrm{g})$ & 5 & & 15 & \\
B - Concentration $(\%)$ & 5 & & 10 & \\
C - Temperature $\left({ }^{\circ} \mathrm{C}\right)$ & 25 & & 50 & \\
\hline Essay & $\mathrm{A}$ & $\mathrm{B}$ & $\mathrm{C}$ rix \\
\hline 1 & $5(-1)$ & $5(-1)$ & $25(-1)$ & $7.03 \pm 0.029$ \\
2 & $15(+1)$ & $5(-1)$ & $25(-1)$ & $12.54 \pm 0.678$ \\
3 & $5(-1)$ & $10(+1)$ & $25(-1)$ & $13.005 \pm 0.007$ \\
4 & $15(+1)$ & $10(+1)$ & $25(-1)$ & $7.035 \pm 0.021$ \\
5 & $5(-1)$ & $5(-1)$ & $50(+1)$ & $6.56 \pm 0.664$ \\
6 & $15(+1)$ & $5(-1)$ & $50(+1)$ & $7.035 \pm 0.035$ \\
7 & $5(-1)$ & $10(+1)$ & $50(+1)$ & $13.025 \pm 0.007$ \\
8 & $15(+1)$ & $10(+1)$ & $50(+1)$ & $13.01 \pm 0.014$ \\
9 & $10(0)$ & $7.5(0)$ & $37.5(0)$ & $9.37 \pm 0.0005$ \\
\hline
\end{tabular}

Source: The authors.

The temperature and acid concentration variables were significant in the extraction of soluble solids, as shown in Figure 2. It can be observed that when the temperature and the acid concentration are in the upper level $(+1)$, the hydrolyzate has a higher percentage of extraction of soluble solids.

Figure 2 - Response surface for the amount of soluble solids extracted as a function of the variables temperature $\left({ }^{\circ} \mathrm{C}\right)$ and acid concentration $(\%)$, with mass quantity in $10 \mathrm{~g}$

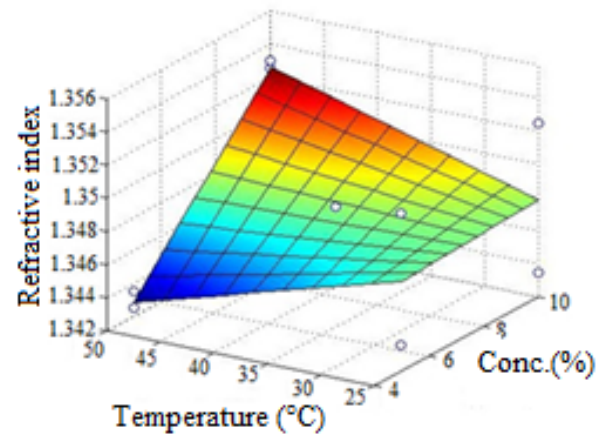

Source: The authors.

According to the data shown in Table 2, in the adjustment of the op value value for the regression and the lack of adjustment was lower than $5 \%\left(1.19 \times 10^{-4}, 4.22 \times 10^{-8}\right.$ respectively), due to the effect of the interactions of the three variables which is significant, indicating that the coefficients of the equation are adequate but there is a lack of fit. Another effect that favored the lack of adjustment is that at low temperature $\left(25^{\circ} \mathrm{C}\right)$, the duplicate had a marked variation in its values and at higher temperatures $\left(50{ }^{\circ} \mathrm{C}\right)$, this does not occur, as was seen in Figure 2.

The results obtained show that the variables employed in this study were significant, but the effects of acid con- centration have a greater influence on extraction, followed by mass and temperature.

Determination by high performance liquid chromatography (HPLC)

Three solutions were characterized by HPLC: solutions 3, 8 and the center point. Table 3 shows the mean concentrations of monosaccharides and disaccharides present in the hemicellulosic hydrolyzate obtained from the pretreatment. According to the data obtained the pretreatment step provided a hemicellulosic hydrolyzate at the central point of $3.515 ; 2.834$ and $1.207 \mathrm{gL}^{-1}$ of glucose, xylose and cellobiose, respectively. For solution 8 , its composition was $8.138 ; 4.578$ and $0.309 \mathrm{gL}^{-1}$ of glucose, xylose and cellobiose, respectively.

In the study by Assumption et al. (2016) performed a pretreatment of $1.45 \%(\mathrm{v} / \mathrm{v}) \mathrm{H}_{2} \mathrm{SO}_{4}$ at $105{ }^{\circ} \mathrm{C}$ for 75 minutes and obtained $3.93 \mathrm{gL}^{-1}$ glucose and $0.91 \mathrm{gL}^{-1}$ xylose. Suhardi et al. (2013) performed the acid pretreatment using 3\% (v/v) H2SO4 for 24 hours and the result obtained was equivalent to $3.8 \mathrm{gL}^{-1}$ glucose.

From the results presented, it is possible to affirm that the pre-treatment used in this work was efficient in relation to the availability of the cellulosic fraction, since there was a significant amount of extracted sugars. It can be observed that glucose and xylose present a greater amount, being these sugars the ones that have greater relevance, since the glucose is representative of the cellulosic fraction, and the xylose is predominant in the hemicellulose (ASSUMPTION et al., 2016). There was no arabinose in any of the solutions analyzed. 
Table 2 - Analysis of variance for the surface adjustment.

\begin{tabular}{cccccc}
\hline & Sun of squares & Degrees of freedom & Avarage sum of squares & F & $p$-value \\
\hline Regression & $2.77 \times 10^{-4}$ & 6 & $4.61 \times 10^{-5}$ & 10.5040 & $1.19 \times 10^{-4}$ \\
Residue & $6.59 \times 10^{-5}$ & 15 & $4.39 \times 10^{-6}$ & & \\
Lack of adjustment & $6.11 \times 10^{-5}$ & 2 & $3.05 \times 10^{-5}$ & 82.1211 & $4.22 \times 10-8$ \\
Pure error & $4.83 \times 10^{-6}$ & 13 & $3.71 \times 10^{-7}$ & & \\
Total & $3.42 \times 10^{-4}$ & 21 & & & \\
\hline
\end{tabular}

Source: The authors.

Table 3 - Mean concentration and standard deviation of the sugars glucose (glu), xylose (xyl) and cellobiose (cel) present in the sugarcane bagasse hydrolyzate obtained by HPLC.

\begin{tabular}{ccccc}
\hline Essay & Glu. $\left(\mathrm{gL}^{-1}\right)$ & Xyl. $\left(\mathrm{gL}^{-1}\right)$ & Cel. $\left(\mathrm{gL}^{-1}\right)$ & Total $\left(\mathrm{gL}^{-1}\right)$ \\
\hline 3 & $0.435 \pm 0.027$ & $1.217 \pm 0.054$ & & 1.652 \\
8 & $8.138 \pm 0.103$ & $4.578 \pm 0.179$ & $0.309 \pm 0.031$ & 13.025 \\
9 & $3.515 \pm 0.020$ & $2.834 \pm 0.007$ & $1.207 \pm 0.058$ & 7.556 \\
\hline
\end{tabular}

Source: The authors.

\section{Conclusion}

The chemical pretreatment with sulfuric acid was efficient in extracting sugars from sugarcane bagasse and the use of factorial planning $\left(2^{3}\right)$ was of fundamental importance to determine the best condition in the removal of these compounds. The results obtained here indicate that temperatures close to the environment are not suitable for extraction (high dispersion), however, mean temperatures $\left(50^{\circ} \mathrm{C}\right)$ provided good extraction values with low dispersion.

For the refractive index, solutions 3, 7 and 8 had higher amount of soluble solids extracted and the only significant main effect is the increase of acid concentration, which increases the refractive index. In the results obtained by liquid chromatography, the presence of glucose, xylose and cellobiose were identified in the solutions and it was concluded that the condition that resulted in a higher sugar extraction was: $15 \mathrm{~g}$ biomass, $10 \%$ acid concentration and temperature at $50{ }^{\circ} \mathrm{C}$. With the concentration of the acid in the upper limit (10\%) the sugar extraction in this work was significant, with $13.025 \mathrm{gL}^{-1}$.

\section{References}

ASSUMPTION, S. M. N. et al. Pre-treatment combined $\mathrm{H}_{2} \mathrm{SO}_{4} / \mathrm{H}_{2} \mathrm{O}_{2} / \mathrm{NaOH}$ to obtain the lignocellulosic fractions of sugarcane bagasse. Journal of Chemical Engineering, São Paulo, v. 8, p. 803-822, 2016. Doi: <http://dx.doi.org/ 10.5935/1984-6835.20160059>
BRIENZO, M.; FERREIRA, S.; VICENTIM, M. P.; SOUZA, W.; SANT'ANNA, C. Comparison Study on the Biomass Recalcitrance of Different Tissue Fractions of Sugarcane Culm. BioEnergy Research, New York, v. 7, ed. 4, p. 1454-1465, 2014. Doi: <http://dx.doi.org/10.1007/s12155-014-9487-8>

CARPIO, L. G. T.; SOUZA, F. S. Optimal allocation of surgacane bagasse for producing bioelectricity and second generation ethanol in Brazil: scenarios of cost reductions. Renewable Energy, Oxford, v. 111, p. 771-780, 2017. Doi: <https://doi.org/10.1016/j.renene.2017.05.015>

CONAB - Companhia Nacional de Abastecimento. Safra da Cana-de-açúcar. Brasília: CONAB, 2017. Available at: <http://www.conab.gov.br>. Accessed on: 24 Apr. 2019.

FERNANDES, A. S.; MIGUEL, E. R. The importance of the use of sugarcane bagasse in the generation of energy in thermoelectric plants. In: SCIENTIFIC MEETING AND UNESALESIAN EDUCATION SYMPOSIUM, 3., 2011, Lins. Anais [...]. Lins, SP: [S. n.], 2011.

FERNANDES, E.; ALVES, R. C.; PAGNOCCA, F. C.; CONTIERO, J.; BRIENZO, M. Sugar and ethanol production process from sugarcane. In: MURPHY, R. Sugarcane: production systems, uses and economic importance. Nova Iorque: Nova Science Publishers, 2017. p. 193-216. 
MILANEZ, A. Y. et al. From promise to reality: how cellulosic ethanol can revolutionize the sugarcane industry - an assessment of competitive potential and public policy suggestions. BNDES Sectorial, Rio de Janeiro, v. 41, n.1, p. 237-294, 2015.

OLADI, S.; AITA, G. M. Optimization of liquid ammonia pretreatment variables for maximum enzymatic hydrolysis yield of energy cane bagasse. Industrial crops and products, Pittsburgh, v. 103, p. 122-132, 2017. Doi: $<$ https://doi.org/10.1016/j.indcrop.2017.02.023>

RAELE, R.; RAELE, R.; BOAVENTURA, J. M. G.; FISCHMANN, A. A.; SARTURI, G. Scenarios for the second generation ethanol in Brazil. Technological Forecasting \& Social Change, Rio de Janeiro, v. 87, p. 205-223, 2014. Doi: <https://doi.org/10.1016/j.techfore.2013.12.010>

RAUD, M.; TUTT, M.; OLT, J.; KIKAS, T. Dependence of the Hydrolysis Efficiency on the Lignin Content in Lignocellulosic Material. International Journal of Hydrogen Energy, Oxford, v. 41, n. 37, p. 16338-16343, 2015. Doi: <https://doi.org/10.1016/j.ijhydene.2016.03.190>

SANTOS-ROCHA, M. S. R.; SOUZA, R. B. A.; SILVA, G. M.; CRUZ, A. J. G.; ALMEIDA, R. M. R. G. Hydrothermal pretreatment of corn residues for second generation ethanol production. Scientia Plena, [Sergipe], v. 3, p. 1-17, 2017
SILVEIRA, M. H. L. et al. Current Pretreatment Technologies for the Development of Cellulosic Ethanol Biorefineries. ChemSusChem, Weinheim, v. 8, n. 20, p. 3366-3390, 2015. Doi: <http://dx.doi.org/10.1002/cssc. 201500282>

SLUITER, A. et al. Determination of structural carbohydrates and lignin in biomass. Colorado: National Renewable Energy Laboratory, 2008. p. 1-16.

SUHARDI, V. S. H.; PRASAI, B.; SAMAHA, D.; BOOPATHY, R. Evaluation of pretreatment methods for lignocellulosic ethanol production from energy cne variety L 79-1002. International Biodeterioration Biodegradation, Barking, v. 85, p. 683-687, 2013. Doi: <https: //doi.org/10.1016/j.ibiod.2013.03.021>

SUN, S.; SUN, S.; CAO, X.; SUN, R. The role of pretreatment in improving the enzymatic hydrolysis of lignocellulosic materials. Bioresource technology, Essex, v. 199, p. 49-58, 2016. Doi: <https://doi.org/10.1016/j. biortech.2015.08.061> 